arise to what extent this is the hidden Lacan or the hidden Žižek. To put it another way, Lacan: The Silent Partners is more of an extension of Žižekian studies than an instigation of Lacanian paranoia.

\title{
Reference
}

Žižek, S. (1996) The Indivisible Remainder: An Essay on Schelling and Related Matters, London and New York: Verso.

Sean Homer

City College, Thessaloniki, Greece

\author{
Kant's Politics: Provisional Theory for an Uncertain World \\ Elisabeth Ellis \\ Yale University Press, New Haven CN, 2005, 272pp. \\ ISBN: 9780300101201
}

Contemporary Political Theory (2008) 7, 111-114. doi:10.1057/palgrave.cpt.9300317

Throughout his many versions of a theory of the effects of commonly held principles on collective life, and most important in his mature theory of the public sphere, Kant directs our attention to the dynamism between our world and our ideals (p. 10).

In Kant's Politics, Ellis provides a new and insightful look at Kant's political philosophy in light of the contemporary debate surrounding deliberative democracy and its critics. Ellis argues that Kant's work contains a priori concepts, which remain relevant to this day, and using an empirical contextual analysis - in the vein of Skinner's recent work on Hobbes — she examines what it was Kant wanted to achieve with his work. Ellis claims to have found in Kant's work - from his pre-critical philosophy through to his late political essays - an 'original theory of political transition that accounts for that part of political change driven by the concrete effects of common political ideals' (p. x).

Ellis comprehensively dismisses the common mistakes made by previous attempts at reading Kant's political theory, and provides a reading that has its application in contemporary political problems. 'Either the reader underestimates the importance of Kant's formal, critical philosophy to the more pragmatical political work, or a reader may apply a mistaken version of this philosophy to Kant's politics' (p. 3). These mistakes take the common form of 
either a narrow rigoristic analysis of his ethics that lead to dogmatic stoicism without the application of his critical method, or the all too common replacement of Kant's epistemology with an ontological interpretation. Ellis has approached Kant's politics with a thorough and holistic interpretation providing a 'Kantian political theory [that] takes the provisional nature of political institutions seriously, focusing less on ideal outcomes than on the places where citizens gain the capacities needed to bring the promise of democratic freedom closer to reality' (p. 2). As far as Kant is concerned, all institutions must be judged according to the possibility of progress. Readers familiar with Kant's Perpetual Peace will be on common ground here.

In Chapter 2 'political judgment', Ellis sets out to free Kant's politics from its teleological ball and chain. As Ellis describes 'If Kant's political theory can be freed from its teleological blinders, then perhaps his very interesting account of freely willed human action in practice - his political theory as opposed to his moral philosophy - might help us improve our analyses of contemporary politics' (p. 42). By removing the 'teleological straitjacket' (p. 43), Ellis provides us with a new perspective, that of provisional right, which adds to Rawls' political theory. In Chapter 3, 'progress toward peace', Ellis examines Kant's famous work Perpetual Peace in some detail, using her examination to begin a more thorough analysis of Kant's 'provisional theory'. Ellis then goes on to confront that very theory with a detailed analysis of Kant's Rechtslehre in Chapter 4 'provisional right'. Ellis identifies Kant's notion of provisional right as the consistent theme throughout this important work. Ellis then uses pragmatic applications of this provisional right in the right of nations, revolution and human rights; thus bringing Kant's work well into the 21 st century.

In Chapter 5 'the judging public', Ellis begins to tie in the notion of publicity and provisional right; 'In Kantian political theory, provisional right provides the standard by which really existing political institutions may be judged; the public sphere provides the mechanism by which actual institutions may be improved' (p. 155). In this chapter, Ellis tackles Kant's The Conflict of the Faculties, and shows how impressed Kant was by the public sphere's apparent lack of care for personal well-being in commenting on political events. Kant, as most readers are well aware, was thoroughly opposed to violence and revolution as a mechanism for change, and advocated change through gradual reform. However Kant — quite courageously — applauds the public sphere within Prussia for its open appreciation of the French revolution. For Kant the public sphere at work — the judging public — was 'evidence of the causality of freedom' (p. 167).

In the final part of the book 'conclusion: a Kantian theory of citizenship', Ellis applies her interpretation of Kant's political theory to the modern debate surrounding citizenship. She uses the book's reading to show Kant 'as a 
dynamic theorist of political change, rather than simply as a philosopher of magisterial, but static ethical principles' (p. 198). This concluding part of the book weighs heavily into the conversation surrounding liberal democratic notions of citizenship at a critical moment in this debate.

What Ellis hopes to achieve through her reworking of Kant's politics, is to find middle ground between deliberative democrats such as Gutmann and Thompson and critics of deliberative democracy such as Shapiro. By bringing Kant's conception of provisional right to the fore, Ellis argues that Kant provides us with a new conception for the transition toward enlightened governance. The mechanism for this transition is the institution of publicity. Ellis argues that Kant sympathizes with the arguments put forward by deliberative democrats for the importance of reasoned argument in the public sphere. For Kant this public sphere works on a social, as opposed to individual level, and one in which change is brought about through the long-term effects of public discourse. It is in this distinction of a long-term effect of publicity that 'Kant's account of the mechanism of publicity contributes a possible resolution to the standoff between deliberative democracy theorists and their critics, one that preserves the originally liberal insights of the theory while remaining empirically viable' (p. 12).

Kant's conception of publicity and the way that publicity functions as a mechanism within the state is of vital importance to Ellis's interpretation of Kant's politics. There are a number of provisions within the institution of publicity that are made apparent through both an appreciation of Kant's philosophy and the empirical mechanisms for change available - that is the 'actual public sphere of the late eighteenth-century world of letters' (p. 14). For Kant, public discourse can only reach reasonable decisions when it is free of all outside interest. In other words, reasoned public debate must be performed in an environment completely free of any self-interest and any outside influence, including political influence. Kant 'seeks to carve out a public sphere free of state regulation in order to protect a realm dedicated to truth from the encroachments of political power' (p. 17). Ellis uses the argument that Kant's moral philosophy creates its own political theory through Kant's political commentary. There is, however, no difference between Ellis' creation of a political theory of transition and Kant's moral philosophy. Though Ellis does bring a new and interesting reading of Kant's political writings, she does not create an ostensibly new political theory - beyond the adaptation of Kant's categorical imperative to the idea of provisional right and the public realm.

Three themes dominate Ellis' conception of Kant's political theory; publicity, the judging public and provisional right. These themes attempt to elucidate from Kant a 'worldly and pragmatic' commitment to human freedom. Kant's notion of freedom - as opposed to nature, the teleological account of causal influence - is one free from politics. It is here that the 
pragmatic notion that Ellis strives for within Kant's political theory, finds a philosophical and ideological barrier. This notion of freedom stands in flagrant opposition to other notions of freedom as being specifically part of politics (Arendt, H. The Human Condition). For Kant freedom provides the essential ingredient to the strength of disinterested publicity and its use of reasoned thought. As Kant himself states; 'that a public should enlighten itself is more possible; indeed this is almost inevitable, if only it is left its freedom' (Kant, What is Enlightenment?). Thus freedom in a Kantian sense is the freedom given by the ruler(s) to their subjects, 'to make public use of their reason' (p.16). Ellis chooses not to recognize Arendt's key concept in political theory - 'The raison d'etre of politics is freedom, and its field of experience is action' (Arendt, H. Between Past and Future). Thus Arendt demonstrates the impotence of Kant's theory of freedom in the political realm.

Despite my reservations surrounding Kant's notion of freedom in the political realm, this book is a thoroughly researched and stunning contribution to neo-Kantian literature. Ellis has not only provided a fresh perspective on Kant, but has also stamped her opinion on the debate surrounding liberal democratic theories of citizenship and deliberative democracy more broadly. Those interested in deliberative democracy, the institution of publicity and the public realm, neo-Kantian political theory, or simply looking for an introduction to Kant's politics would be well served to consider Kant's Politics: Provisional Theory for an Uncertain World. Ellis is to be congratulated for being co-awarded the 'First Book Award' 2006 from the Foundations of Political Theory section of the American Political Science Association recently held in Philadelphia, USA.

Alex Karolis

University of Canberra, Australia

\section{The Politics of the Governed: Reflections on Popular Politics in Most of the World.}

Partha Chatterjee

Columbia University Press, New York, 2004, 173pp.

ISBN: 0231130635.

Contemporary Political Theory (2008) 7, 114-119. doi:10.1057/palgrave.cpt.9300318

This book is an original and important contribution to understanding movements of the excluded in postcolonial societies. The concrete discussion is mainly of India, but the potential relevance is broader, particularly in the 